\title{
Probable Protein E4, Human Papillomavirus Type 1
}

National Cancer Institute

\section{Source}

National Cancer Institute. Probable Protein E4, Human Papillomavirus Type 1. NCI

Thesaurus. Code C17318.

Probable protein E4 is encoded by the human papillomavirus type $1 \mathrm{E} 4$ gene. This protein is an early phase product and its function is unknown. 